University of Chicago Law School

Chicago Unbound

Journal Articles

Faculty Scholarship

1945

\title{
The Task of Law. The North Law Lectures, Franklin and Marshall College
}

Max Rheinstein

Follow this and additional works at: https://chicagounbound.uchicago.edu/journal_articles

Part of the Law Commons

\section{Recommended Citation}

Max Rheinstein, "The Task of Law. The North Law Lectures, Franklin and Marshall College," 12 University of Chicago Law Review 224 (1945).

This Article is brought to you for free and open access by the Faculty Scholarship at Chicago Unbound. It has been accepted for inclusion in Journal Articles by an authorized administrator of Chicago Unbound. For more information, please contact unbound@law.uchicago.edu. 
a work of supererogation, namely, a declaration that nothing in the code should be construed as restricting or interfering with press freedom, as guaranteed by the Constitution. Mr. Roosevelt signed the code, saying that the press freedom clause was "pure surplusage." "While it has no meaning," said the President, "it is permitted to stand because it could have no such legal effects as would bar its inclusion." Maybe this was a great victory for Col. McCormick and the Tribune and maybe, too, 989 angels can dance on the head of a pin.

Mr. Kinsley's final big cause is the Associated Press case, in which Col. McCormick is a co-defendant. Now, this is a very peculiar and very interesting case, but it happens at the present time to be under advisement by the Supreme Court of the United States, and just why, under the circumstances, Mr. Kinsley included it in his book is not altogether apparent.

It is obvious that Col. McCormick considers the suit a personal affront to him by the Department of Justice and the New Deal, but it is not so obvious why it was treated here. The stated objective of the book is to tell the story of how the Tribune has fought for the rights of the press, "and how these rights have been redefined and reaffirmed, to the benefit of everyone who seeks to express opinions concerning his city, state, or federal government." Until the Supreme Court hands down its decision in the Associated Press case, no one can say that these rights "have been redefined and reaffirmed."

Mr. Kinsley wrote a whole book about the Chicago Tribune's fight for press freedom. It would have a more kindly and sympathetic audience if the Chicago Tribune itself did not abuse that freedom by the pollution of its own news columns with its publisher's hatreds and prejudices, instead of confining them where they belong, to his editorial page. Mr. Kinsley wrote a whole book, but we think, from the story he had to tell, he should have held it down to a column and a half.

RALPH COGHLAN*

Task of Law, The: The North Law Lectures, Franklin and Marshall College. By

Roscoe Pound. Lancaster, Pa.: Franklin and Marshall College, r944. Pp. 94. \$I.50.

This, as far as I know, latest book of the Dean is a collection of three lectures which were delivered, as it seems, before the faculty and student body of a Pennsylvania College. The scope of these lectures is indicated by their titles: "Why Law?," "What Is Law?," and "What May Be Done through Law." Needless to say that both the Dean's learning and his wisdom are exemplified in these discussions. Needless to say, too, that the reader will find in them strong expressions of the Dean's dislike of certain trends of recent American life. There is a tendency to identify the particular system of law of nineteenth-century England and the United States with law in general. There are passages which, at least, seem to indicate that absolutism is regarded as inevitable, wherever the scheme of the classical common law is modified, and there is at least one passage which cannot go unchallenged. Statutory administrative agencies are said to "consider themselves empowered to put the claims of the employee on a higher plane of value and to ignore those of the employer whenever they come in conflict." Such an idea might conceivably occur to a layman who derives his knowledge of government adjustment of labor disputes from newspaper headlines, but it is strange

* Editor of the Editorial Page, St. Loutis Post-Dispatch.

I Italics by the reviewer. 
to see it come from a man of the learning of the Dean, just as it is difficult to see why adjudication according to flexible standards is praiseworthy when it is exercised by a tribunal called "court" and damnable when it is practiced by a tribunal called "board." However, these and other prejudices of the Dean have been sufficiently discussed by others and, after all, as André Gide has expressed it, "prejudices are the pillars of civilization." Even where we do not share them, the convictions of a great man are entitled to respect. However one may feel about the controversial passages, one must welcome this succinct statement of Dean Pound's thought on the very basic problems of jurisprudence.

Although the lectures seem to have been delivered before a lay audience, the Dean has not refrained from cutting deeply and attacking difficult problems. In general his style is so clear and simple that he could well afford doing so. But one may well doubt whether the difficult theories of Duguit, Kelsen, and Lundberg have been sufficiently clarified in the two pages which the author could devote to them. Apart from this minor point, however, one can experience, even in reading, the excitement which his audience must have felt when it was in live contact with one of the great masters of our age.

The attractive form in which the lectures have been published by Franklin and Marshall College deserves to be mentioned.

MAX RHEINSTEIN*

Public and Private Government. By Charles Edward Merriam. New Haven: Yale University Press, 1944. Pp. ix, 98. \$r.75.

These published lectures compress much of the philosophy of government which has characterized Professor Merriam's teaching by word, book, and example. Compression, as we learn from experience with dehydrated foods, does not preserve sympathetically the original flavor as partisans of a commodity relish it, yet those who have been disciples will catch now and then the characteristic roll of the voice or of the eye. The theme is stated in the first lecture-the ubiquitous nature of government. The apparently simple generalization raises implications that should lead to insight and tolerance, as we are led to re-survey and re-appraise how we act in even the simplest associations. It leads the author to examine afresh, in his second lecture, the idea of sovereignty, whose present meaning he finds in the symbol of unity of the state amidst the diversity of human associations and interests, and so "a determination to decide as well as to deliberate." "If sovereignty speaks as one having authority, it will be because it speaks as one having reason, justice, liberty, human dignity, as the coauthors of its authority." There follow two chapters in which the resultant problem of organization is explored in the light of fresh experience and the attacks upon democratic political systems.

What a person so experienced in affairs, so eager a searcher in varied fields for new insights into politics, is transmitting to his hearers is significant. It rests upon a profound (and not mawkish or sentimental) faith in persons and in the emergence of organic systems of government to serve their common needs; an insight that pierces the surface of current events to find deeper currents of science and technology in production and the study of man which may be utilized by men to achieve a democratic society; and a kind of grim aggressiveness in puncturing the facile and defeatist general-

* Max Pam Professor of Law, University of Chicago. 